Article

\title{
Place Innovative Synergies for City Center Attractiveness: A Matter of Experiencing Retail and Retailing Experiences
}

\author{
Malin Lindberg ${ }^{1, *}$, Kristina Johansson ${ }^{1}$, Helena Karlberg ${ }^{2}$ and Johanna Balogh ${ }^{2}$ \\ ${ }^{1}$ Department of Business Administration, Technology and Social Sciences, Luleå University of Technology, 97187 Luleå, \\ Sweden; E-Mails: malin.lindberg@ltu.se (M.L.), kristina.johansson@ltu.se (K.J.) \\ 2 Piteå Science Park, 94163 Piteå, Sweden; E-Mails: helena.karlberg@piteasciencepark.se (H.K.), \\ johanna.balogh@piteasciencepark.se (J.B.) \\ * Corresponding author
}

Submitted: 25 June 2018 | Accepted: 15 August 2018 | Published: 24 January 2019

\begin{abstract}
By investigating the occurrence of place innovative synergies between retail and tourism in a small-sized Swedish city, this article advances knowledge on how city center attractiveness can be enforced in a rural context with competing online shopping and suburban/out-of-town shopping centers. Previous studies of city center attractiveness, place innovation, and social innovation help distinguish innovative intertwinement of correlated trends of experiencing retail and retailing experiences, augmenting customer experiences through place-based characteristics. Interviews, workshops, and participatory observations with entrepreneurs, business promoters, and municipality representatives reveal three dimensions of place innovative synergies in city center attractiveness: 1) innovative variance in city center retail and tourism, 2) innovative interwovenness between the city center identity and its configuration, content, and communication, and 3) innovative interaction between retailers and tourism entrepreneurs in city center events. A key question is whether synergies in temporal events and everyday commerce are sufficiently combined, in order to engender encompassing renewal.
\end{abstract}

\section{Keywords}

attractiveness; city center; city identity; innovation; retail; Sweden; synergy; tourism

\section{Issue}

This article is part of the issue "The Transformative Power of Urban Planning through Social Innovation", edited by Torill Nyseth (UiT, The Arctic University of Norway, Norway) and Abdelillah Hamdouch (University of Tours, France).

(C) 2019 by the authors; licensee Cogitatio (Lisbon, Portugal). This article is licensed under a Creative Commons Attribution 4.0 International License (CC BY).

\section{Introduction}

Innovative renewal of cities, destinations, regions and other types of places has been increasingly highlighted in research and practice over the last decade, as a means to ensure the attractiveness of these places in the perceived competition for residents, tourists, entrepreneurs, investments, and events (Arefi, 2014; Brandsen, Cattacin, Evers, \& Zimmer, 2016; Moulaert \& Van den Broeck, 2018; Nyseth \& Viken, 2009; Syssner, 2010). Many city centers, especially in rural areas, are struggling to find new solutions in order to remain attractive because of growing trends of online shopping and suburban/out-of-town shopping centers (Fertner, Groth,
Herslund, \& Carstensen, 2015; Karlsson \& Nilsson, 2017; Olsson \& Bernhard, 2018; Teale, 2013; Wahlberg, 2016; Weltevreden \& Van Rietbergen, 2007). Such solutionsand the process to develop them-may be understood in terms of social innovation, as they imply new figurations or combinations of social practices that meet societal challenges (cf. Brandsen et al., 2016; Howaldt, Kaletka, Schröder, \& Zirngiebl, 2018). The challenge of city center attractiveness is one of the more comprehensive societal challenges faced by rural areas, in terms of depopulation, services decline, and urbanity norms (cf. Lindberg, 2017). A solution for maintained city center attractiveness is perceived in augmented customer experiences, adding place-based values of local stores to the exchange of 
payment and products (Coca-Stefaniak \& Carroll, 2015; Johnson, Kim, Mee Mun, \& Lee, 2015; Morandi, 2011). In this article, this is conceptualized as 'experiencing retail', which is related to the corresponding trend of 'retailing experiences' in the tourism industry, where unique customer experiences are tailored based on the specific character of the place where they are consumed (Pine \& Gilmore, 1999; Sundbo \& Sørensen, 2013).

Through their co-location in city centers, tourism and retail may engender synergies in their similar reorientation toward place-based customer experiences. This article empirically investigates the occurrence of such synergies in a single case study of Piteå, a small city in northern Sweden struggling to ensure city center attractiveness in a rural context with competition from both nearby cities and online shopping. The main purpose of the study is to advance knowledge on how city center attractiveness relates to the correlated trends of experiencing retail and retailing experiences. The research is conducted in terms of 'place innovative synergies', defined as correlations that boost renewing development paths in cities, destinations, and other types of places (cf. Bernhard, Olsson, \& Lundh Snis, 2018; Ericson, Holmqvist, \& Wenngren, 2016; Lindberg, Ericson, Gelter, \& Karlberg, 2015; Lindberg, Gelter, \& Karlberg, 2017; Lundh Snis, Olsson, \& Bernhard, 2017; Olsson \& Bernhard, 2018). Such synergies imply innovative reconfigurations of spatialized social relations, where the concept of social innovation provides valuable perspectives (cf. Moulaert \& Van den Broeck, 2018).

\section{Theoretical Framework}

\subsection{City Center Attractiveness}

A growing number of studies scrutinize the attractiveness of various places-e.g., city centers-for residents, tourists, entrepreneurs, investors, and other stakeholders in the light of the perceived competition from online shopping, suburban/out-of-town shopping centers, etc. (e.g., Coca-Stefaniak \& Carroll, 2015; Fertner et al., 2015; Hart, Stachow, \& Cadogan, 2013; Karlsson \& Nilsson, 2017; Litvin, 2005; Olsson \& Bernhard, 2018; Pazder, 2011; Sandahl \& Lindh, 1995; Wahlberg, 2016; Weltevreden \& Van Rietbergen, 2007). Attractiveness can be defined as attitudes, perceptions, and patronage behaviors that pull people to a particular place (Karlsson \& Nilsson, 2017; Teller \& Elms, 2012). A study demonstrates that the concentration of shops, restaurants, cafés, and other establishments in Italian city centers implies a spatial continuity that generates scale economies, enabling them to compete with suburban/out-of-town shopping malls (Morandi, 2011). The importance of mixed offers in the city centers is also demonstrated in studies from, e.g., the Netherlands, Poland, Sweden, and the UK, including shops, services, activities, culture, entertainment, events, parks, architecture, housing, workplaces etc. (Hart et al., 2013; Karlsson \& Nilsson, 2017;
Öner, 2017; Pazder, 2011; Wahlberg, 2016; Weltevreden \& Van Rietbergen, 2007). A distinction is made between a city's tangible elements of culture, nightlife, shopping, infrastructure, housing, business parks, etc., on the one hand, and intangible elements of perceived personality, emotions, and values on the other (Zenker, 2011). Others conclude that the overall atmosphere or ambience affects city center attractiveness, based on studies in the Netherlands and the UK (Hart et al., 2013; Weltevreden \& Van Rietbergen, 2007).

Positive emotional and affective bonding with a particular place has been conceptualized as 'place attachment' (Johnson et al., 2015; Karlsson \& Nilsson, 2017). This bonding is linked to the 'identity values' of city centers, identified as crucial for their attractiveness when competing with suburban shopping centers (Morandi, 2011). In addition, 'place branding' and 'place marketing' may serve to reinforce the local identity among existing residents and visitors, while securing visibility to potential ones (Anholt, 2010; Foroudi, Gupta, Kitchen, Foroudi, \& Nguyen, 2016; Karlsson \& Nilsson, 2017; Warnaby \& Medway, 2004; Zenker, Braun, \& Petersen, 2017). The accessibility of the city center and its shops and services has been noted to further affect attractiveness in studies from Germany, Sweden, and the UK, highlighting the importance of car parks, public transports, walkingdistances, orientation, etc. (Monheim, 1998; Öner, 2017; Teale, 2013; Teller \& Elms, 2010, 2012). Some studies from the UK and the US note the impact of co-located commercial and historic cores on city center attractiveness, albeit with a tricky balance act between commercial functions and cultural heritage preservation (CocaStefaniak \& Carroll, 2015; Litvin, 2005). Others investigate the attractiveness of small and rural towns in Denmark, Poland, and Sweden (e.g., Fertner et al., 2015; Pazder, 2011; Wahlberg, 2016), concluding that it is especially affected by service sector restructuring, demographic change, and community engagement (Fertner et al., 2015).

\subsection{Retail and Tourism Attractiveness}

Retail is distinguished as a major driver of urban attractiveness, partly by influencing the spatial configuration (Karlsson \& Nilsson, 2017; Morandi, 2011; Saraiva \& Pinho, 2017; Teller \& Elms, 2012). The variety of retail outlets, the product range, and the opening hours in city centers are, in studies from the Netherlands, Sweden, and the UK, noted to be highly valued by customers, whose shopping loyalty is clearly linked to the perceived attractiveness of the city center (Hart et al., 2013; Teller \& Elms, 2010, 2012; Wahlberg, 2016; Weltevreden \& Van Rietbergen, 2007). The impact of store appearance and physical space functionality on customers' perception of service quality has, in studies from the Netherlands and Italy, been proven to affect their desire to spend time and money there (de Nisco \& Warnaby, 2013; Weltevreden \& Van Rietbergen, 2007). As agglomerated 
stores in high streets and shopping malls compete with each other for customers, while at the same time cooperating in operational and marketing matters, combined competition and cooperation seems-according to a study from the UK-to improve the performance in such agglomerations (Teller, Alexander, \& Floh, 2016). Online shopping has been proven to decrease the number of trips made to city centers in the Netherlands and also the number of purchases in city center stores (Weltevreden \& Van Rietbergen, 2007). Identified solutions to the e-commerce challenge include improved range, convenience, and accessibility of local shops, as well as augmented customer experiences as consumers increasingly seek a more emotional shopping experience (Johnson et al., 2015; Morandi, 2011; Weltevreden \& Van Rietbergen, 2007). These experiences encompass the generated reactions among customers in rational, emotional, sensational, physical, and spiritual terms (Gentile, Spiller, \& Noci, 2007), adding place-based values to the exchange of payment and products (cf. Johnson et al., 2015). These can be enhanced through increased intertwinement between digital and local shopping (Neslin et al., 2006; Schmitt, 2003). In this article, the intensified focus on experiences in retail is conceptualized as 'experiencing retail'.

Some studies focus on the role of tourism in city center attractiveness based on cases in Canada, the Czech Republic, Finland, France, Germany, Ireland, Italy, the Netherlands, Spain, and the UK (e.g., Bridaa, Meleddub, \& Pulinac, 2012; Figini, Castellani, \& Vici, 2009; Gibson \& Hardman, 1998; Valls, Sureda, \& Valls-Tuñon, 2014). There are, for example, studies of Europe's eleven biggest cities as tourist attractions (Valls et al., 2014), and more specific studies of cultural tourism in Dutch, French, Italian, Portuguese, and US city centers, e.g., museums and cultural heritage sites (Bridaa et al., 2012; Litvin, 2005; Russo \& Van Der Borg, 2002). One study from Italy notes that the impact of tourism on a city center may be economic, socio-cultural, or environmental, affecting the attitudes among local residents towards tourism (Figini et al., 2009). While the economic impact of tourism is generally positive, the study notes that socio-cultural and environmental impact tend to be negative as a whole. The same study concludes that tourists and residents are forced to share the most important resource for tourism: the territory. This makes it important to consider the desires, aspirations, and attitudes of local residents in tourism planning. An encompassing trend of unique customer experiences is distinguished in tourism, often harnessing the specific character of the place where they are consumed (cf. Pine \& Gilmore, 1999; Sundbo \& Sørensen, 2013). Here, this trend is conceptualized as 'retailing experiences'.

\subsection{Place Innovative Synergies}

The demonstrated importance of mixed offers in the city centers and the growing role of the experience economy in city center attractiveness alongside retailfocused approaches has inspired studies on the relation between tourism and retail in such settings, based on cases in, e.g., Canada, France, Turkey, the UK, and the US (e.g., Coca-Stefaniak \& Carroll, 2015; Getz, 1993; Karlsson \& Nilsson, 2017; Rabbiosi, 2015; Vural-Arslan, Dostolu, Köprülü-Babanci, \& Aknctürk, 2011). Some of these scrutinize the strategic mix of tourist-oriented facilities and services with retail and other traditional business land uses in the revitalization of historic commercial districts and cultural heritage districts in Canada, Norway, Turkey, and the US (e.g., Bernhard et al., 2018; Getz, 1993; Litvin, 2005; Lundh Snis et al., 2017; VuralArslan et al., 2011). Another study investigates tourismretail synergies in the strategic promotion of leisure shopping for urban tourists in France (Rabbiosi, 2015). Synergies engendered by city center events, based on culture, sports, etc., have also been studied in, e.g., Canada, Greece, Italy, Sweden, the UK, and the US (e.g., Hart et al., 2013; Karlsson \& Nilsson, 2017; Kurtzman, 2005; Oppewal, Alexander, \& Sullivan, 2006; Wahlberg, 2016). One study exposes that non-commercial activities and events are highly valued by visitors to a small-town center in Sweden (Wahlberg, 2016), while another reveals that sponsorship of sports events positively affects the attractiveness of retail stores in the UK (Oppewal et al., 2006). Higher economic resilience among city centers with main income generation through retail or office rental is indicated in another study in Canada and the US, compared to those primarily relying on tourism and leisure (Gibson \& Hardman, 1998).

Studies show that city center synergies imply complex interaction between various industries, establishments, and actors, in order to ensure their vibrancy, viability, innovativeness, and resilience (Brańka, Coca-Stefaniak, \& Plichta, 2016; Coca-Stefaniak \& Carroll, 2015; Gibson \& Hardman, 1998; McAteer \& Stephens, 2011). This usually includes continuous negotiations between conflicting interests and perspectives (cf. Brandsen et al., 2016; Evans, 2013; Lindberg, 2017). A study of rural development paradigms in the UK discerns that insufficient acknowledgement of the social diversity of a place and contesting interpretations of its historical trajectories may serve to commodify rural space for consumption by tourists rather than to ensure its attractiveness for residents and other stakeholders (Evans, 2013). Inspired by previous studies on how places are renewed and reinvented in interaction between various processes, components, and actors (e.g., Arefi, 2014; Moulaert \& Van den Broeck, 2018; Nyseth \& Viken, 2009; Syssner, 2010), the study investigates correlations that boost renewing development paths in terms of 'place innovative synergies'. The study of these synergies draws upon previous studies of 'place innovation', defined as multi-actor processes aspiring to renew, recreate, or redefine cities, destinations, or other types of places (Bernhard et al., 2018; Ericson et al., 2016; Lindberg et al., 2015; Lindberg et al., 2017; Lundh Snis et al., 2017; Olsson \& Bernhard, 2018). 
As a scientific and practical concept, place innovation specifically pinpoints the innovation perspective in place development, since pre-existing concepts of 'place making', 'place branding', 'place management', 'place reinvention', and 'place-based innovation' rarely address innovation per se and, if so, rarely with references to mainstream innovation literature. The concept of place innovation was incrementally elaborated through dialogues between innovation researchers, tourism entrepreneurs, tourism destination organizations, and municipality representatives in Sweden, and has hitherto been applied in empirical studies of Swedish and Norwegian cases (Bernhard et al., 2018; Ericson et al., 2016; Lindberg et al., 2015; Lindberg et al., 2017; Lundh Snis et al., 2017; Olsson \& Bernhard, 2018).

Place innovation helps pinpoint and enforce innovative interwovenness between a place's specific cultural, social, and geographical identity, on the one hand, and its crucial components of physical configuration (e.g., architecture and design), content (e.g., commercial and public services, events, activities), and communication (e.g., place branding, place marketing) on the other (Lindberg et al., 2015, 2017). It further acknowledges the innovative synchronization of parallel management processes, e.g., spatial planning, destination design, business promotion, cultural development, and social cohesion. Place innovation thus enables the identification of innovative ways to interconnect relevant elements and institutions when striving to maintain or improve the attractiveness of a place among existing and potential residents, tourists, investors, and entrepreneurs. The elaboration of place innovation was based on the innovation studies sub-fields of social innovation, userdriven innovation, and service innovation (Lindberg et al., $2015,2017)$. Among these, social innovation provides a valuable lens to distinguish innovative reconfigurations of spatialized social relations in territorial development (cf. Moulaert \& Van den Broeck, 2018). Urban studies have accordingly made significant contributions to social innovation theory and social innovation processes have been studied in both urban and rural contexts throughout the world (Brandsen et al., 2016; Howaldt et al., 2018; Lindberg, 2017). Matching the complexity of the societal challenges addressed in social innovation processes, studies across the globe have highlighted the impact of local policy regimes on social innovation trajectories (e.g., Brandsen et al., 2016) alongside the imperative of actively involving local stakeholders (e.g., Lindberg, 2017) and establishing new cross-organizational and cross-sectorial constellations (e.g., Moulaert \& Van den Broeck, 2018). This matches the complex management of various actors and interests highlighted in studies of city center synergies (Brańka et al., 2016; Coca-Stefaniak \& Carroll, 2015; Gibson \& Hardman, 1998; McAteer \& Stephens, 2011). Social innovation thus provides valuable perspectives when investigating place innovative synergies between the correlated trends of experiencing retail and retailing experiences.

\section{Research Design}

The study is designed as a single case study, using qualitative methods to explore the multiple-dimensional topic of place innovative synergies (cf. Bailey, 2008; Silverman, 1997; Yin, 2009). The qualitative approach serves to open "the 'black box' of how social phenomena are constituted in real time", reaching beyond subjective meaning to language, representation, and social organization (Silverman, 1997, p. 3). As place innovative synergies arise from social and socio-material relations that are yet to be thoroughly studied, qualitative methods enable explorative identification of relevant variables and correlations (cf. Bailey, 2008). This is further enhanced by the case study design, suitable for exploring contemporary phenomena in real-world contexts with multiple potential variables (cf. Yin, 2009). The studied case is constituted by Piteå, a small-sized city with 42,000 residents and persistent demographic growth during the 2000's (Statistics Sweden, 2016). It is located on the coastal line of northern Sweden, in a rural area approximately 900 kilometers north of the capitol Stockholm and 100 kilometers south of the Polar Circle. The total land area of the municipality is 3086 square kilometers, with a population density of 13 inhabitants per square kilometer (Statistics Sweden, 2016). Every year, Piteå has about 1,1 million visitors, of which $20 \%$ are international visitors.

According to the municipality's official website, Piteå is characterized by its cozy atmosphere, shopping, and events (e.g., large conferences, concerts, festivals, tournaments), attracting both tourists and residents (Piteå kommun, 2018b). Its city center attractiveness is perceived to be challenged by suburban/out-of-town shopping centers in two larger cities nearby-Luleå 50 kilometers north and Skellefteå 80 kilometers south-as well as online shopping (Destination Piteå, 2016b; Tyréns, 2014). The establishment of local suburban/out-of-town shopping centers has been actively counteracted by locating the largest supermarkets for convenience goods in the city center, retail of durable goods to the main shopping street and two city gallerias, and retail of low-price goods to an area within walking distance from the city center (Destination Piteå, 2016a, 2016b; Tyréns, 2014). City center attractiveness is further enhanced by the maintained vibrancy of Piteå's main shopping street, with a variety of malls and shops representing both local establishments and national/global chains, as well as recurring events, such as music concerts, a city festival, and an international football tournament (Destination Piteå, 2016a, 2016b; Tyréns, 2014). These efforts to ensure city center attractiveness in a rural context with competition from nearby cities and online shopping, make Piteå an enlightening case when investigating the occurrence of place innovative synergies in relation to the correlated trends of experiencing retail and retailing experiences.

The study aims to create 'socially robust knowledge', where the process and results are validated through continuous dialogues with those who possess practi- 
cal insights in the studied area (cf. Nowotny, Scott, \& Gibbons, 2001). The study encompassed dialogues between researchers, municipality representatives, business promoters, and entrepreneurs engaged in a joint $R \& D$ project on attractive city centers. The project was managed by Luleå University of Technology and Piteå Science Park during 2017-2019, with funding from The Swedish Retail and Wholesale Council (Handelsrådet), The R\&D Fund of the Swedish Tourism and Hospitality Industry (BFUF), and Sparbanken Nord. The main goal of the project was to develop knowledge and concepts concerning place-innovative synergies between retail and tourism for attractive city centers. This study, carried out as part of the project, included interviews, workshops, participatory observations, and document studies in order to obtain rich, triangulated data on perceived synergies (cf. Bailey, 2008; Yin, 2009). Participatory observations of 20 local and national events-e.g., lectures, seminars, and workshops-on city center attractiveness, tourism, and retail were carried out in 2017-2018. These were documented through graphic recording, summarizing the events in art sketches. In parallel, interviews and workshops were carried out in a two-step procedure. Initially, stakeholders representing the municipality, business promoters, and entrepreneurs were interviewed during 2017 by researchers from the university and project partners from the science park. This included 13 semi-structured interviews, focusing on the interviewed actors' perception of retail and tourism relations in Piteå's city center and their own role in enhancing existing or potential synergies. The interviews were recorded and transcribed in order to capture detailed perceptions and formulations. The document studies included structured reviews of printed and digital material-e.g., reports, brochures, and websites-produced by the municipality, the local destination management organization, and other public/private organizations depicting and analyzing Piteå's main characteristics, city center attractiveness, and retail/tourism offers.

A thematic analysis (cf. Guest, MacQueen, \& Namey, 2012) was subsequently carried out on the collected data, pinpointing retail and tourism relations and synergies in Piteå's city center. The preliminary analysis was further developed through discussions with the stakeholders at two workshops, arranged as part of the project at the end of 2017. The discussions were led and facilitated by researchers from the university and project partners from the science park. A second round of interviews was thereafter carried out in 2018, in order to provide further details on indicated synergies during two city center events: a city festival and a football tournament. This encompassed 10 semi-structured interviews both with former informants and event organizers. The interviews were recorded, transcribed, and thematically analyzed, after which the analysis was further refined through discussions with the stakeholders at a workshop later in 2018, arranged and facilitated by researchers from the university and project partners from the science park.

\section{Findings}

The document studies reveal that Piteå is marketed towards tourists and residents by its cozy atmosphere, shopping, and events-e.g., large conferences, festivals, and tournaments (Piteå kommun, 2018b). The attractiveness for residents is further promoted by the possibility of combining a career with a good life without stress and car queues, with affordable housing and good childcare, school and elderly care. Piteå's main slogan is accordingly formulated as "this is where you come when you come home" (Tyréns, 2014, p. 7). According to a tourism communication guide produced by the local destination management organization, Piteå is to be promoted by the concept "Arctic Lifestyle" that is endorsed by the regional tourism destination Swedish Lapland (Destination Piteå, 2016a). The guide further pinpoints Piteå's "soul" as encompassing three main elements: 1) pride over the beautiful nature, warmhearted residents, and exciting ideas, 2 ) innovativeness with bold and creative ideas and milieus, 3) hostesship welcoming everyone to shape the future and participate in happenings. The guide also distinguishes Piteå's attractiveness in its small-town spirit, team spirit, creative city, forests, river, and archipelago. Other reports depict Piteå's city center as a strong commercial district, characterized by its history as a wooden town and Sweden's oldest shopping street (Piteå kommun, 2018b; Tyréns, 2014). The stakeholder interviews convey a recurrent perception that Piteå's city center is undergoing renewal, with the construction of modern apartment complexes, the recent inauguration of a luxury design hotel, and reconstruction of the court-house square to be inaugurated as part of Piteå's 400th anniversary in 2021 (see Figure 1).

In the interviews, Piteå's city center attractiveness is perceived as dependent upon seasonal variations: flourishing during the summer with a popular sea bath, an international football tournament, and a big city festival, while dozing during winter, with the exception of some ski sports events and large professional/public conferences. Accordingly, tourists mainly visit Piteå during the summer, primarily from other parts of Sweden as well as Norway, Germany, Italy, and China (Resurs, 2016). The perceived competition from suburban/out-of-town shopping centers in larger cities nearby, in combination with increasing trends of online shopping, are in the interviews and documents conceptualized as major challenges to Piteå's city center attractiveness (Destination Piteå, 2016b; Tyréns, 2014). Local establishment of suburban/out-of-town shopping centers has, however, been actively counteracted, by locating Piteå's largest supermarkets for convenience goods in the city center, retail of durable goods to the main shopping street and two city gallerias, and retail of low-price goods to an area within walking distance, while maintaining a vibrant main shopping street and recurring city events (Destination Piteå, 2016a, 2016b; Tyréns, 2014). 


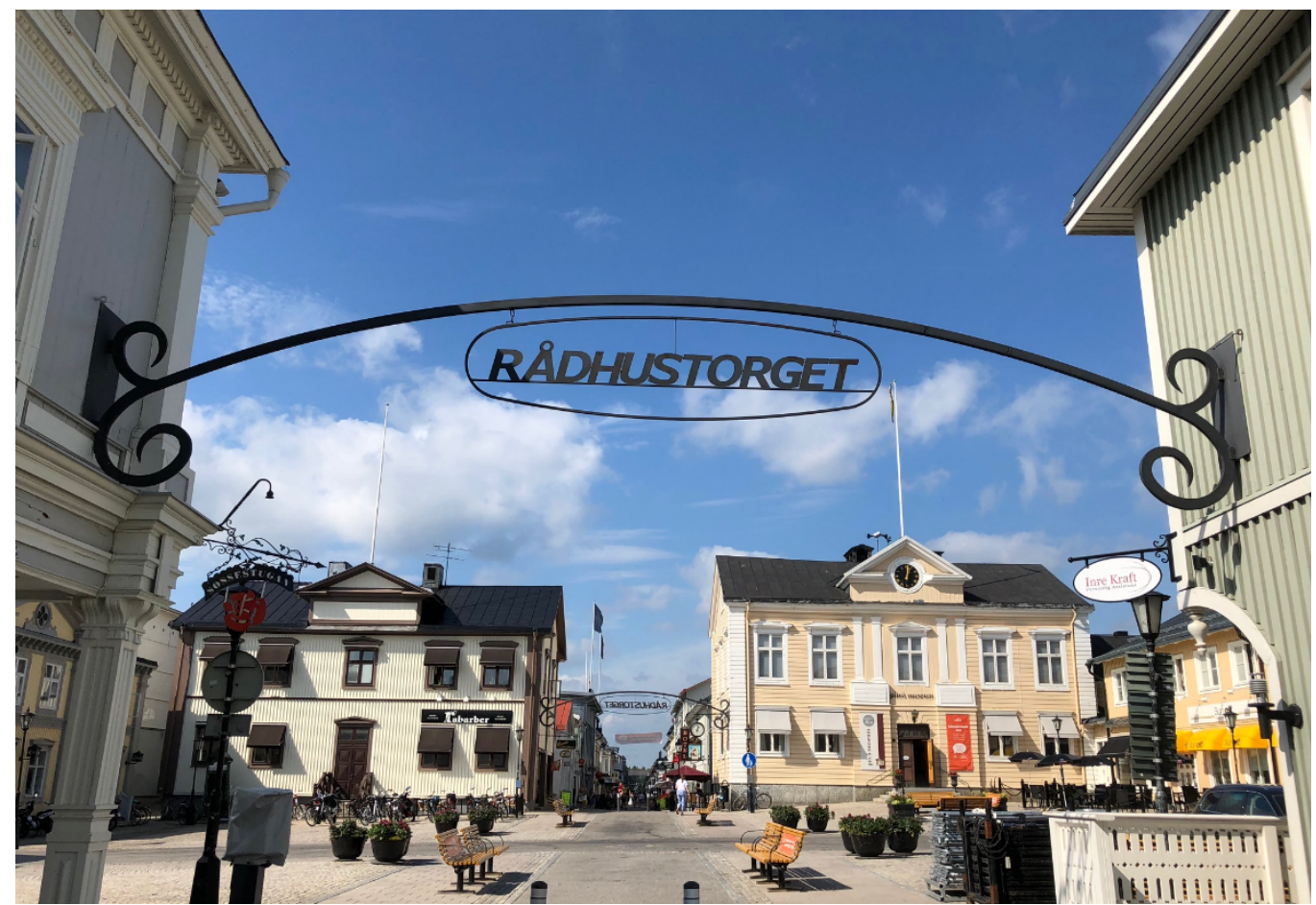

Figure 1. Piteå’s court-house square (photographer Johanna Balogh).

\subsection{Flourishing Tourism and Struggling Retail}

The economic turnover in Piteå's retail and tourism industries has steadily grown during the 2000's (HUI Research, 2016; Resurs, 2016). The annual turnover in its retail industry is 2,437 million SEK (approximately 238 million euro), almost equally distributed on convenience goods and durable goods (HUI Research, 2016). Piteå's overall sales index is 89 (i.e., that $89 \%$ of all potential purchases are made locally), of which the sales index for convenience goods is 92 and for durable goods 85 . A report on Piteå's retail development, produced jointly by the municipality and the local destination management organization, perceives increased sales index to 100 as crucial for maintained city center attractiveness (Tyréns, 2014). Retail is one of the largest employment industries in Piteå, besides healthcare, education, and manufacturing (Statistics Sweden, 2016). The annual turnover in Piteå's tourism industry is 548 million SEK (approximately 53 million euro), with its 12 hotels and 14 camping facilities as the single largest contributors (Resurs, 2016). As the tourism industry does not constitute a unified statistical category in Sweden, it is difficult to make an exact estimation of its employment numbers, but combined statistics on employment in Piteå's hotels and restaurants, as well as in its personal and cultural services, indicate that it employs half as many people as retail.

In the stakeholder interviews, contrasting perceptions of retail and tourism in Piteå are conveyed. While the tourism industry is perceived as flourishing, with significant growth in profits and establishments during the last years, the retail industry is conveyed as struggling with the competition from online and external shopping:
The tourism industry is the fastest growing sector in the world. That is fantastic, and they estimate an annual growth by three percent, globally. And then you have industries such as retail, which are having a hard time, generally. (Representative from the destination management organization)

In the interviews, tourism is understood to contribute to increased customers and sales in retail, while retail needs to better harness the sales potential among tourists, e.g. through tailored opening hours, offerings, and events. The tourism entrepreneurs were thereto perceived as more innovative and inclined to change than the retail entrepreneurs. This was generally explained by the latter's hesitant attitude towards actively induced change, prioritizing their everyday business rather than innovative efforts:

Local retailers need to make as much effort as the online retailers in their operations. To constantly improve. Piteå's retailers seem rather uninterested in doing that. (Representative from the destination management organization)

Some examples of innovative retailers were, however, acknowledged at the stakeholder workshops. This included local stores that had strategically augmented the place-based customer experiences through unique atmospheres and offerings. One of them offers locally designed clothes, inspired by themes from Piteå. Another one is designed as a corner shop from the 1940's, situated in the maritime cultural heritage site Western Dock in the city center (see Figure 2 ), where it is accompanied 


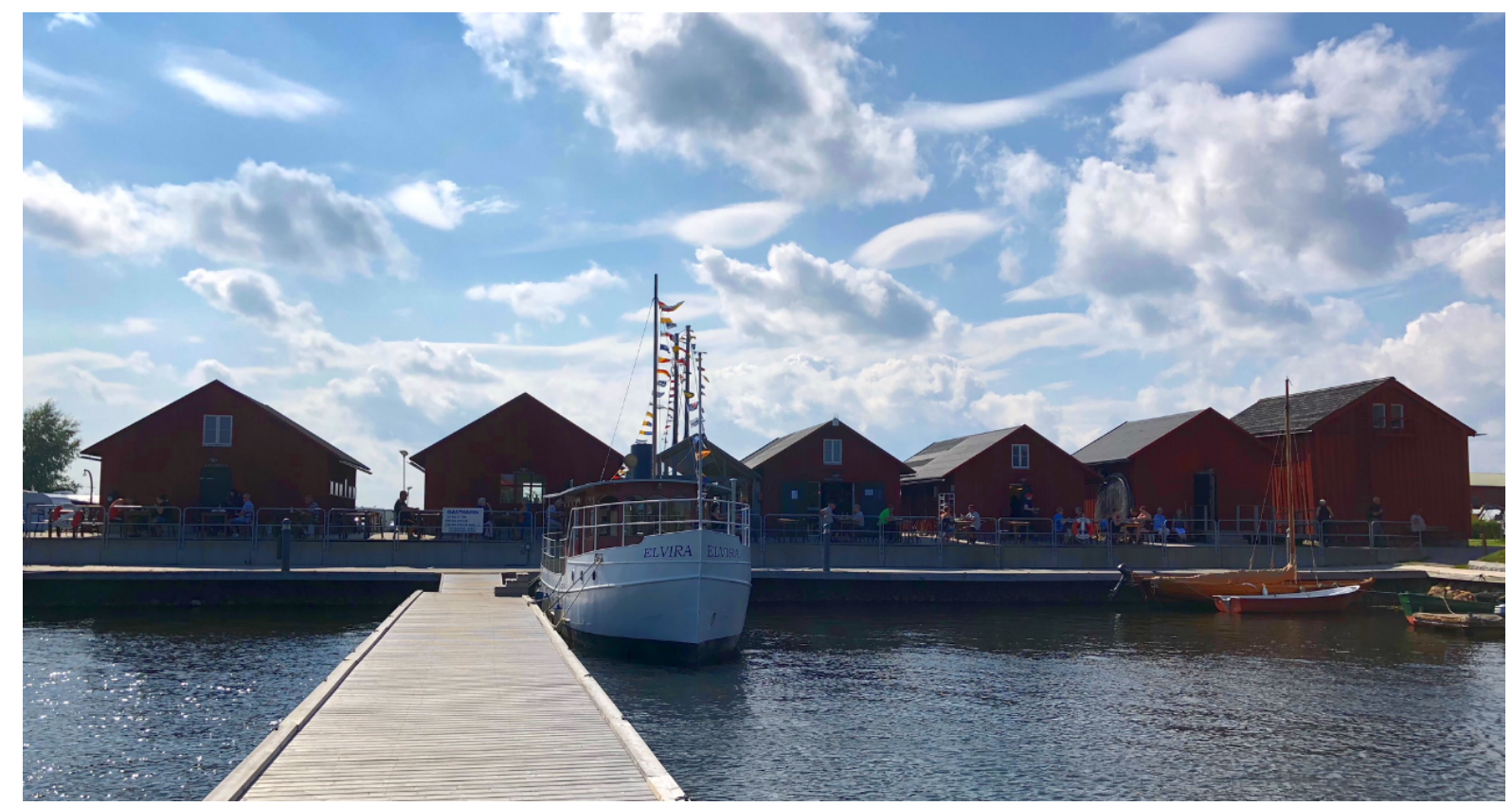

Figure 2. The Western Dock in Piteå (photographer Johanna Balogh).

by a boat café, kayak rentals, accommodation in one of Piteå's oldest buildings from the 16th century, as well as recurring flea-markets, auctions, and cultural activities. The official website of the Western Dock describes the area in the following manner:

The place, environment, history, and feeling seize you in a special way. The history of the Western Dock spans several centuries... and the city-centered location still attracts visitors from far and near. The Western Dock is a lovely little spot, where you can enjoy the tranquility and history around the boathouses, in a city-centered context. (Western Dock, 2018)

The participatory observations of local and national events distinguish a number of trends in retail and tourism, influencing and inspiring Piteå's entrepreneurs, business promoters, and public servants. A prominent trend is augmented: unique customer experiences in both industries, based on place-based qualities such as personalized reception and services, cultural history, natural surroundings, or local products and services. An adjacent trend is to match increasingly well-informed customers with knowledgeable and transparent staff. The permeating digitalization trend has enforced new ideas of communication channels, such as push notices on cellphones when customers pass stores or other facilities, as well as enhanced webrooming preceding customer's visits to physical stores or facilities. Outlet-services for collecting web-purchased items in local stores and showrooms physically exhibiting web-available goods are adjacent trends. The digitalization trend also encompasses 'open tourism', where tourists and residents are actively involved in the production and consumption of services and experiences (see Figure 3).
The digitalization trend further enables augmented customer experiences through 'mixed realities', intertwining virtual and physical elements in the production and consumption of goods and services (see Figure 4).

\subsection{Retail and Tourism Synergies}

Some statistical synergies are perceivable between Piteå's tourism and retail industries, as local shopping amounts to a third of all tourist expenditures, followed by a quarter to accommodation, a fifth to restaurants and transportation respectively, and less than a tenth to activities (Resurs, 2016). In the interviews, synergies are mainly perceived around activities, offers, and events. This includes, for example, chartered shopping buses from nearby cities, thematic events such as girls' night, and value vouchers for local stores to hotel guests. The shopping malls (see Figure 5) are described as especially inclined to enhance synergies:

We [one of the shopping malls] arrange activities in order to create new reasons to visit the local stores and the city center....For example, we've built a roof terrace where you can view Piteå from an entirely new perspective and then eat, drink, and hang out up there. We've also installed an ice rink there....We arrange various activities throughout the year, including...fashion shows, art exhibitions, children's activities, etc. (Retail entrepreneur)

We [another shopping mall] cooperate with the local university, where there are students in music, media, and previously also in experience design.... They have performed in the galleria-playing, singing, and dancing-using it as a scene for public promotion. 


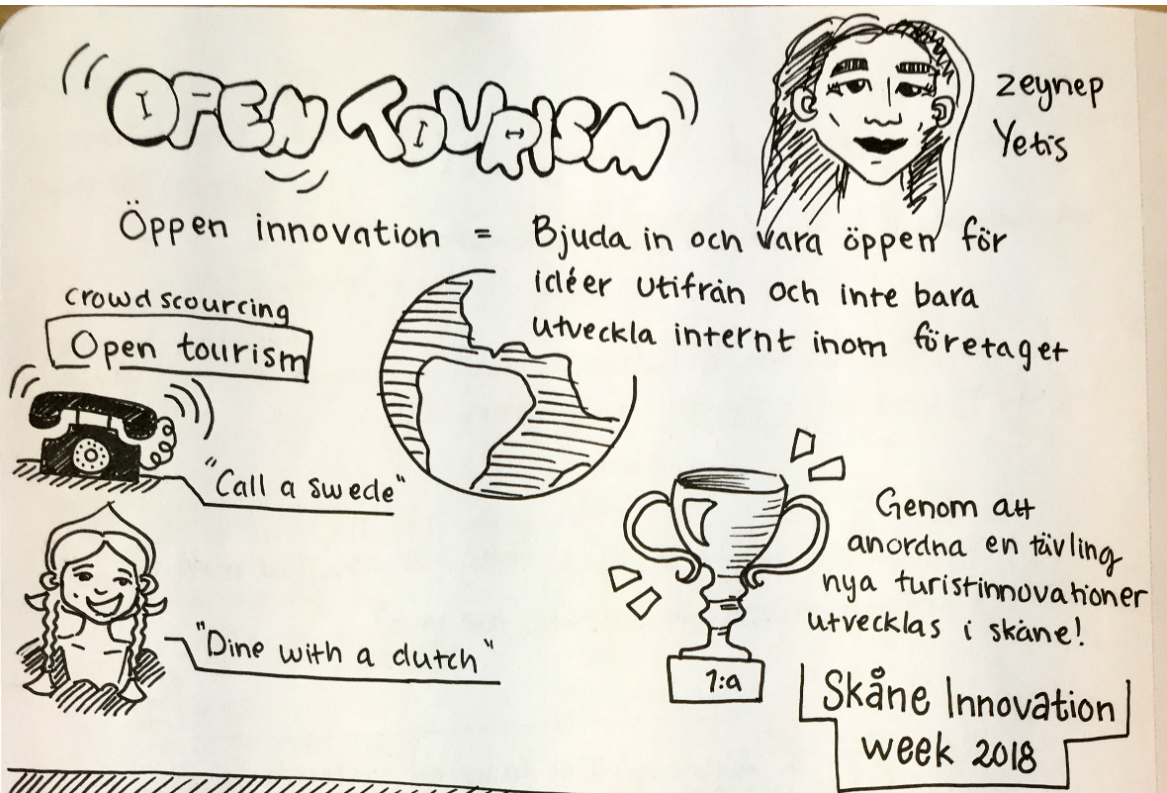

Figure 3. Open tourism (graphic recorder Johanna Balogh).

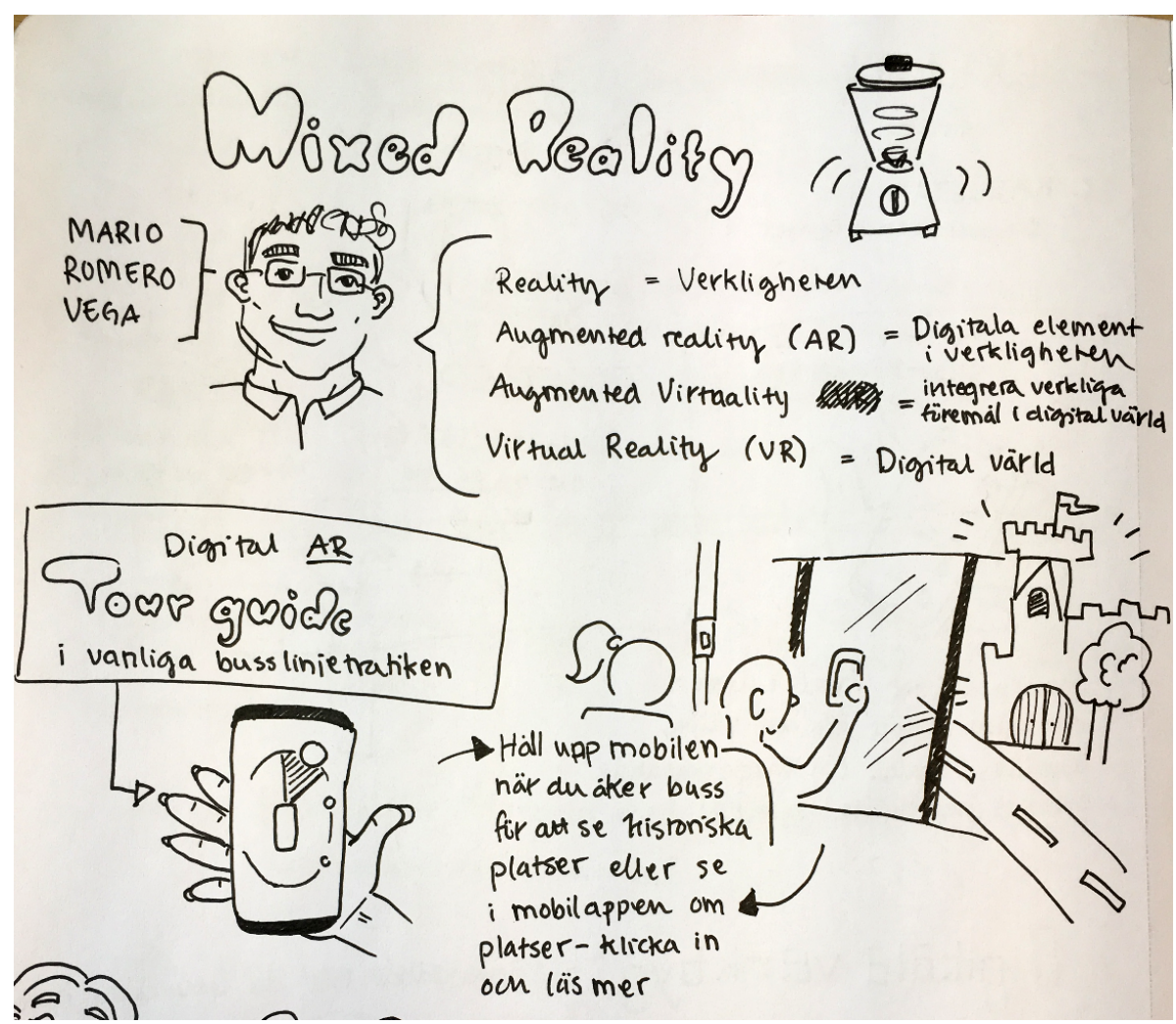

Figure 4. Mixed reality (graphic recorder Johanna Balogh).

That is profitable for both parties, also bringing the university closer to the city center.

Synergies are also perceived in annual events, such as the city festival Piteå Dansar och Ler and the football tournament Piteå Summer Games. The city festival fills the streets of Piteå every summer, with performances by well-known artists, dance, markets, funfair, and other activities. With its free entrance, it attracts around 100,000 visitors and residents. The turnover for the event organization amounts to 3,5 million SEK (approximately 0,34 million euro). Piteå Summer Games is the second largest football tournament in Sweden, and top-five in the world, attracting about 35,000 participants and spectators per day, from all parts of Sweden and 30 other countries. The turnover for the event organization amounts to 12 million SEK (approximately 1,2 million euro) and for the community as a whole, about 60 million SEK (approx- 


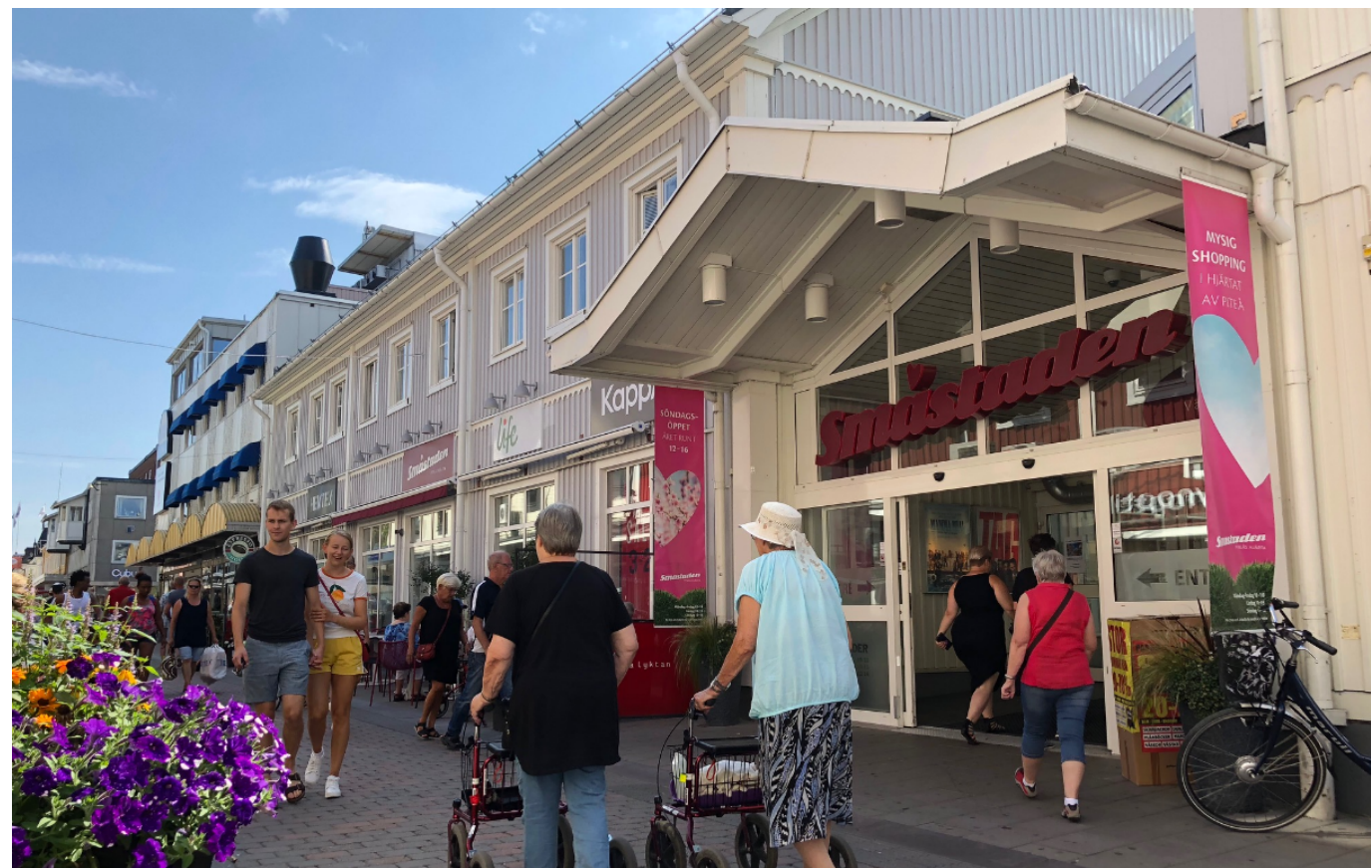

Figure 5. Shopping mall in Piteå (photographer Johanna Balogh).

imately 5,9 million euro). The follow-up interviews on these events indicate that they are generally positively perceived among city center entrepreneurs:

The entrepreneurs in the city center seem very happy about the existence of Piteå Dansar och Ler. They especially appreciate the high number of people around. (Representative from the municipality)

It's truly great that Piteå has such a large, fine tournament [Piteå Summer Games], and it's really important that it may prevail and attract people to the city. (Retail entrepreneur)

The football tournament is esteemed to be especially profitable for the retailers in the city center:

Piteå Summer Games is a really important event for the retail....There are so many accompanying parents, coaches, youth, and insane numbers of people coming here. The hotels and restaurants are fully booked, and they come here to actually do some shopping. (Retail entrepreneur)

During the tournament, the stores extend their opening hours and arrange Midnight Sun Shopping for a whole evening. Local stores market the tournament in their store windows, offer tailored merchandise, e.g., football shirts, and sponsor the tournament. Some stores and hotels provide discounts to the football tournament tourists.

We [the shopping mall] cooperate directly with Piteå Summer Games, promoting each other during the tournament. We highlight the tournament in the galleria and they promote our opening hours and merchandise. (Retail entrepreneur)

The sport shops are especially perceived to profit from the tournament and one of them establishes temporary stores at the football fields. The tournament is initiated with a team parade through the city center and several bievents are arranged in the city center during the tournament, such as cultural performances, trade markets, and flea markets. In order to make the football tournament visitors stay longer in Piteå, adjacent leadership conferences have been arranged, as well as package trips with e.g., midnight cruising on icebreakers. Extended stays with local activities and experiences could be further elaborated, according to some of the interviewees.

The city festival is esteemed as profitable mainly for the tourism industry in the city center:

It is one of Piteås biggest events. Most hotels are fully booked and also restaurants. (Representative from the destination management organization)

The festival is perceived as less profitable for the retailers in the city center:

The festival is usually not so meaningful for the retailers....It attracts other types of people to the city center...who prefer to shop in the temporary street market. (Retail entrepreneur)

There is a widespread perception that established retail is hampered by the festival, as store fronts are hidden behind festival market stalls: 
I know that many [of the retailers] are irritated since [the market stalls] hide their stores, so that the customers don't see their stores or can't enter. (Retail entrepreneur)

Some local retailers do however sponsor the festival, adjust their opening hours and harness the influx of people for adjacent events, although not to the same extent as during the football tournament. One idea proposed in the interviews is to arrange more of the festival events within the stores and thereby attract more visitors to shop. Another idea is to correspondingly move out the stores into the streets during the festival.

\subsection{Synergy Management}

Synergies between Piteå's tourism and retail industries are partly coordinated by the local destination management organization-Destination Piteå-organized as an economic association of tourism and retail entrepreneurs. Over the last decade, Destination Piteå has been actively engaged in several strategic development processes regarding industrial development and city center attractiveness on local and regional levels (cf. Destination Piteå, 2016a, 2016b). According to the interviews, in Destination Piteå, synergies seem to mainly be discussed as a practical matter of coordinating opening hours, public transports, and city decoration, rather than as a strategic, innovative matter:

An example of discussed topics [in Destination Piteå] is local and regional transports, and how to cooperate there. Commonly, the bus time tables are tailored to the residents. Absolutely not from a tourism perspective....Opening hours is also a huge topic. Should we be open Sundays? What availability should we have when competing with online services, available around the clock? There is also cooperation around specific themes, e.g., how to promote Christmas in Piteå. (Tourism entrepreneur and representative from the destination management organization)

Destination Piteå is closely related to local and regional public governance, by carrying out public assignments from the municipality to promote tourism and retail and development projects financed by regional authorities. The policy intertwinement is further enforced by the integration of Destination Piteå's official website in the municipality website (Piteå kommun, 2018a). The municipality manages several development processes in Piteå's city center, including planning and reconstruction of public spaces, promotion of business and entrepreneurship, arrangement of citizen dialogues, administration of licensing requests, etc. (Piteå kommun, 2018b). Opinions were expressed during the workshops that the coordinating and guiding functions of the municipality ought to be further developed, e.g., by designating a city manager. At the regional level, Norrbotten Region and Norrbotten's
County Administrative Board enforce and coordinate local development processes through various policy instruments, including financing, networks, and strategy documents (Länsstyrelsen i Norrbotten, 2018; Region Norrbotten, 2018). At the national level, the Swedish government manages and inspires local development processes through similar instruments, as well as public laws (Regeringen, 2018).

\section{Discussion}

The empirical investigation of Piteå reveals both confirming and contradicting evidence of place innovative synergies in its city center in terms of correlations between retail and tourism that boost renewing development paths. Such synergies seem - on a comprehensive level-to be engendered by the conveyed identity of Piteå as cozy and homely, with a "soul" of pride, warmheartedness, hostesship, and innovativeness reflecting the overall ambience and identity values previously identified as crucial for city center attractiveness in studies from, e.g., the Netherlands and the UK (cf. Hart et al., 2013; Morandi, 2011; Weltevreden and Van Rietbergen, 2007). Place attachment is further enforced by the marketing/branding of Piteå's small town character, team spirit, maritime history, wooden architecture and natural surroundings (cf. Anholt, 2010; Foroudi et al., 2016; Johnson et al., 2015; Karlsson \& Nilsson, 2017; Syssner, 2010; Warnaby \& Medway, 2004). The maintenance of these identifying traits seems to require an innovative variance of services, activities, and facilities in Piteå's city center retail and tourism, reflecting the previously proven importance of mixed offers, variety of outlets, and products, as well as combined tangible and intangible elements for city center attractiveness in studies from e.g., Canada, the Netherlands, Norway, Turkey, Sweden, the UK, and the US (cf. Hart et al., 2013; Karlsson \& Nilsson, 2017; Lindberg et al., 2015, 2017; Öner, 2017; Pazder, 2011; Teller \& Elms, 2010, 2012; Wahlberg, 2016; Weltevreden \& Van Rietbergen, 2007; Zenker, 2011). Such a variance is actively promoted in Piteå through the ongoing city center reconstruction with new attractive apartments, a design hotel and court-house square renewal as well as the central location of both convenience, durable, and low-price goods retail, in combination with maintained vibrancy of the historic main shopping street, the maritime cultural heritage site Western Dock, and arrangement of city center events.

Piteå's place-based identity is harnessed in several of these processes, emphasizing its distinctiveness both in the built environment-due to Piteå's history as a wood-built and maritime town-and in the retail structure, with its historic shopping street and variety of malls and shops representing both local establishments and national/global chains. Innovative interwovenness is thus distinguishable between Piteå's conveyed cultural, social, and geographical identity on the one hand, and its components of configuration, content, and commu- 
nication on the other, in line with the concept of place innovation (cf. Lindberg et al., 2015, 2017). This intertwinement seems, however, to be complicated and contested as it involves complex interaction between various industries, establishments, and actors, with continuous negotiations of conflicting interests and perspectives, in correspondence with the reconfigurations of spatialized social relations highlighted in social innovation studies (cf. Brandsen et al., 2016; Brańka et al., 2016; Coca-Stefaniak \& Carroll, 2015; Evans, 2013; Gibson \& Hardman, 1998; Lindberg, 2017; Lindberg et al., 2015, 2017; McAteer \& Stephens, 2011; Moulaert \& Van den Broeck, 2018; Nyseth \& Viken, 2009). This is, for example, evident in the contrasting interview accounts of Piteå's flourishing tourism industry and struggling retail industry, while statistics expose positive economic developments in both industries and five times as high turnover and twice as many employees in retail than in tourism. Together with the adjacent perception of Piteå's retailers as less innovative than the tourism entrepreneurs, this may be understood as contesting perspectives and priorities between retail and tourism regarding city center identity and strategy (cf. Evans, 2013).

By prioritizing their everyday business, retailers dispute both the promoted identity of Piteå as innovative, with bold and creative ideas and milieus, and the advocacy of innovative renewal as mandatory for maintained city center attractiveness (cf. Arefi, 2014; Brandsen et al., 2016; Moulaert \& Van den Broeck, 2018; Nyseth \& Viken, 2009; Syssner, 2010). Despite being conceptualized as an attitude issue in the interviews, the perceived uninnovativeness among retailers may just as well be related to structural factors. The fact that Piteå's city center retail encompasses many small shops with few employees, with increasingly slimmed organizations, and prize-pressure due to increased competition from larger and online establishments, probably restricts the retailers' room for innovative strategizing in their everyday work. Some retailers do, however, embrace Piteå's innovative identity, by harnessing local themes and heritage in their store designs and product offerings, e.g., as part of the maritime cultural heritage site Western Dock and the shopping malls' roof terrace, ice rink, and student performances. These examples provide some evidence of place innovative synergies between the correlated trends of experiencing retail and retailing experiences, where unique customer experiences are tailored upon specific place characteristics in both retail and tourism (cf. Johnson et al., 2015; Morandi, 2011; Pine \& Gilmore, 1999; Sundbo \& Sørensen, 2013; Weltevreden $\&$ Van Rietbergen, 2007). As these trends are actively promoted and discussed at local and national events, the interviews and workshops expose a widespread awareness of them among Piteå's entrepreneurs and public servants. The practical intertwinement of these trends seems, however, to be hampered by the overly practical, administrative orientation of the interaction between retail and tourism entrepreneurs in the local destination management organization, focusing on opening hours, public transports, and city decoration rather than strategic, innovative interaction. Some innovative interaction is perceivable in Piteå's annual summer events when the streets, hotels, and restaurants are crowded with tourists and residents during the city festival, Piteå Dansar och Ler, and the football tournament, Piteå Summer Games.

Identified interaction between retail and tourism during these events include mutual marketing, sponsorship, tailored offers and merchandise, adjusted opening hours, bi-events, and package trips. These interactions are, however, unevenly distributed, as the football tournament is perceived as more profitable for Piteå's retailers than the city festival due to the events' differing focus, target groups, and physical configurations. The exposure and accessibility of local stores are, for example, limited during the city festival, as they are hidden behind market stalls, in contrast to the demonstrated importance of accessibility for city center attractiveness in studies from Germany, Sweden, and the UK (cf. Monheim, 1998; Öner, 2017; Teale, 2013; Teller \& Elms, 2010, 2012). Innovative potentials are consequently perceived in moving stores out in the streets during the events and locating event-related activities in stores. The complex coordination of various actors and components, identified as crucial in previous studies on place renewal, thus appears incomplete in Piteå's annual events (cf. Brandsen et al., 2016; Brańka et al., 2016; Coca-Stefaniak \& Carroll, 2015; Evans, 2013; Gibson \& Hardman, 1998; Lindberg, 2017; Lindberg et al., 2015, 2017; McAteer \& Stephens, 2011; Moulaert \& Van den Broeck, 2018; Nyseth \& Viken, 2009). This is further confirmed by the call for improved municipal coordination of city center synergies, potentially enhancing innovative linking of parallel management processes and new cross-organizational/sectorial constellations, as advocated in both place innovation and social innovation studies (cf. Lindberg et al., 2015, 2017; Moulaert \& Van den Broeck, 2018). Innovative linking and constellations would require acknowledgement of contesting interpretations of Piteå's identity and historical trajectories, as well as its social and industrial diversity. This may ensure attractiveness among a multitude of existing and potential residents, tourists, investors, and entrepreneurs and counteract the negative sociocultural impact of tourism, as noted in previous studies from Italy and the UK (cf. Evans, 2013; Figini et al., 2009). A hitherto rather unexploited development path regards, for example, Piteå as a winter city, as part of the "Arctic Lifestyle" concept endorsed by the regional tourism destination Swedish Lapland, where previous studies in e.g., Canada, Finland, Japan, Sweden, Switzerland, and the US provide inspiration (cf. Davies, 2015; Henke, 2006; Kostenius, 2018; Pressman, 2004; Rönkkö, 2014).

\section{Conclusion}

In the results, three dimensions of place innovative synergies are distinguished that seem to enforce city center 
attractiveness: 1 ) innovative variance in city center retail and tourism, 2) innovative interwovenness between the city center identity and its configuration, content, and communication, 3 ) innovative interaction between retailers and tourism entrepreneurs during city center events. The innovativeness varies, however, between and within these dimensions. Variance is, for example, discerned in the extent to which Piteå's conveyed identity as cozy and homely, with characterizing maritime and wooden heritage is exploited in tourism and retail. Such exploitation is most prominent in the first and second dimensions of innovative variance and interwovenness, and less in the third dimension of innovative interaction during events. Variance is also detected in the conflicting perspectives and priorities regarding city center identity and strategy between retail and tourism, depicting the former as struggling and un-innovative and the latter as flourishing and innovative. Variance is further distinguished in the extent to which the correlated trends of experiencing retail and retailing experiences are actively synchronized, as efforts to augment customer experiences do not necessarily imply concrete cooperation between retail and tourism. Such cooperation does take place during Piteå's annual city center events, but not necessarily with a focus on augmenting customer experiences. The occurrence of place innovative synergies thus varies in both form and extent, as the innovative variance, interwovenness, interaction between retail and tourism in the depicted city center events, shopping mall efforts, and the maritime cultural heritage site reach different arenas and scales.

The key question is whether synergies in temporal events and everyday commerce are sufficiently combined, in order to engender encompassing, sustainable renewal in city center attractiveness. This study helps discern relevant indicators for estimating that, but further studies are required in order to confirm their relevance and their causal links in various geographical and demographical contexts. Such studies could specifically investigate the impact of local policy regimes and stakeholder involvement on place innovation trajectories, highlighting factors of social diversity and contesting interpretations of the place's historic and contemporary identity. The main practical implications of the study include improved insights into place innovative strategies for city center attractiveness, underlining the need to enhance cross-industrial synergies through complex and diligent coordination of concerned actors, components, and processes. This includes innovative intertwinement of the correlated trends of experiencing retail and retailing experiences, enabling concrete and strategic interaction between retail and tourism. It also includes innovative delineation and exploitation of place identity for improved attractiveness, acknowledging social diversity and multifaceted perspectives. Among tourism and retail entrepreneurs, place innovative synergies may be encouraged through arenas for concrete interaction, exploring mutually profitable pathways to inno- vative intertwinement of experiencing retail and retailing experiences.

\section{Acknowledgements}

The study was funded by The Swedish Retail and Wholesale Council (Handelsrådet), The R\&D Fund of the Swedish Tourism and Hospitality Industry (BFUF), and Sparbanken Nord.

\section{Conflict of Interests}

The authors declare no conflict of interests.

\section{References}

Anholt, S. (2010). Definitions of place branding: Working towards a resolution. Place Branding and Public Diplomacy, 6(1), 1-10.

Arefi, M. (2014). Deconstructing placemaking: Needs, opportunities, and assets. Abingdon: Routledge.

Bailey, K. (2008). Methods of social research. New York, NY: Free Press.

Bernhard, I., Olsson, A. K., \& Lundh Snis, U. (2018). Stakeholder collaboration for place innovation: Recaps and Visions in local re-generation. Paper presented at the 21th Uddevalla Symposium, Luleå, Sweden.

Brandsen, T., Cattacin, S., Evers, A., \& Zimmer, A. (Eds.). (2016). Social innovations in the urban context. New York, NY: Springer.

Brańka, S., Coca-Stefaniak, A., \& Plichta, J. (2016). City centres as places for strategic cooperation through active city management. The significance of trade entities. Scientific Annals of Economics and Business, 63(1), 133-141.

Bridaa, J. G., Meleddub, M., \& Pulinac, M. (2012). Understanding urban tourism attractiveness: The case of the archaeological Ötzi museum in Bolzano. Journal of Travel Research, 51(6), 730-741.

Coca-Stefaniak, A., \& Carroll, S. (2015). Traditional or experiential places? Exploring research needs and practitioner challenges in the management of town centres beyond the economic crisis. Journal of Urban Regeneration and Renewal, 9(1), 35-42.

Davies, W. K. D. (2015). Winter cities. In W. K. D. Davies (Ed.), Theme cities: Solutions for urban problems (pp. 277-310). New York, NY: Springer Berlin Heidelberg.

de Nisco, A., \& Warnaby, G. (2013). Shopping in downtown: The effect of urban environment on service quality perception and behavioural intentions. International Journal of Retail \& Distribution Management, 41(9), 654-670.

Destination Piteå. (2016a). Identitet och kommunikationsguide för besöksnäringen [Identity and communication guide for the tourism industry. Report in the EU Regional Fund projekt Destination Capacity Building in Swedish Lapland]. Piteå: Destination Piteå.

Destination Piteå. (2016b). Strategi för utveckling av han- 
deln i Piteå [Strategy for retail development in Piteå]. Piteå: Destination Piteå.

Ericson, Å., Holmqvist, J., \& Wenngren, J. (2016). Place innovation: Using design thinking in live cases. In C. Boks, J. Sigurjonsson, M. Steinert, C. Vis, \& A. Wulvik (Eds.), Proceedings of NordDesign 2016 (pp. 398-317). Trondheim, Norway.

Evans, N. J. (2013). Policy persistence and cultural resistance: The (re-)development of horticulture in the Vale of Evesham. Journal of Rural and Community Development, 8(3), 29-48.

Fertner, C., Groth, N. B., Herslund, L., \& Carstensen, T. A. (2015). Small towns resisting urban decay through residential attractiveness. Findings from Denmark. Geografisk Tidsskrift-Danish Journal of Geography, 115(2), 119-132.

Figini, P., Castellani, M., \& Vici, L. (2009). Estimating tourism effects on residents: A choice modelling approach to the case of Rimini. In A. Matias, P. Nijkamp, \& M. Sarmento (Eds.), Advances in tourism economics: New developments (pp. 145-164). Heidelberg: Physica.

Foroudi, P., Gupta, S., Kitchen, P., Foroudi, M. M., \& Nguyen, B. (2016). A framework of place branding, place image, and place reputation Antecedents and moderators. Qualitative Market Research: An International Journal, 19(2), 241-264.

Gentile, C., Spiller, N., \& Noci, G. (2007). How to sustain the customer experience. European Management Journal, 25(5), 395-410.

Getz, D. (1993). Planning for tourism business districts. Annals of Tourism Research, 20(3), 583-600.

Gibson, C., \& Hardman, D. (1998). Regenerating urban heritage for tourism. Managing Leisure, 3(1), 37-54.

Guest, G., MacQueen, K. M., \& Namey, E. E. (2012). Applied thematic analysis. Thousand Oaks, CA: SAGE.

Hart, C., Stachow, G., \& Cadogan, J. W. (2013). Conceptualising town centre image and the customer experience. Journal of Marketing Management, 29(15/16), 1753-1781.

Henke, M. (2006). Urban winter: Applying winter city planning principles to improve livability at the University of Winnipeg (master thesis). Winnipeg: University of Manitoba.

Howaldt, J., Kaletka, C., Schröder, A., \& Zirngiebl, M. (Eds.). (2018). Atlas of social innovation: New practices for a better future. Dortmund: Sozialforschungsstelle, TU Dortmund University.

HUI Research. (2016). HUI Research. Retrieved from www.hui.se

Johnson, K. K., Kim, Y. H., Mee Mun, J., \& Lee, J. Y. (2015). Keeping customers shopping in stores: Interrelationships among store attributes, shopping enjoyment, and place attachment. The International Review of Retail. Distribution and Consumer Research, 25(1), 20-34.

Karlsson, S., \& Nilsson, M. (2017). What makes a city centre attractive from a consumer perspective? A comparison between residents and visitors of Kristianstad city centre (Unpublished Bachelor's thesis). Kristianstad: Högskolan i Kristianstad.

Kostenius, C. (2018). Future health. In J. Frishammar \& A.. Ericson (Eds.), Addressing societal challenges (pp. 71-85). Luleå: University of Technology.

Kurtzman, J. (2005). Economic impact: Sport tourism and the city. Journal of Sport Tourism, 10(1), 47-71.

Länsstyrelsen i Norrbotten. (2018). Norrbotten's County Administrative Board. Retrieved from www.lansstyrelsen.se/norrbotten

Lindberg, M. (2017). Promoting and sustaining rural social innovation. European Public \& Social Innovation Review, 2(2), 48-60.

Lindberg, M., Ericson, A., Gelter, J., \& Karlberg, H. (2015). Social change through place innovation. Design Research Journal, 13(1), 9-13.

Lindberg, M., Gelter, J., \& Karlberg, H. (2017). Tourism networking for regional place innovation in Swedish Lapland. International Journal of Innovation and Regional Development, 7(4), 257-272.

Litvin, S. W. (2005). Streetscape improvements in an historic tourist city a second visit to King Street, Charleston, South Carolina. Tourism Management, 26(3), 421-429.

Lundh Snis, U., Olsson, A. K., \& Bernhard, I. (2017). The old town district: Not only a scenery backdrop. stakeholders' perspectives in urban re-generation. Paper presented at the 20th Uddevalla Symposium, Trollhättan, Sweden.

McAteer, B., \& Stephens, S. (2011). Town centre management: A solution to the challenges facing urban centres in Ireland? Journal of Place Management and Development, 4(3), 264-271.

Monheim, R. (1998). Methodological aspects of surveying the volume, structure, activities and perceptions of city centre visitors. GeoJournal, 45(4), 273-287.

Morandi, C. (2011). Retail and public policies supporting the attractiveness of Italian town centres: The case of the Milan central districts. Urban Design International, 16(3), 227-237.

Moulaert, F., \& Van den Broeck, P. (2018). Social innovation and territorial development. In J. Howaldt, C. Kaletka, A. Schröder, \& M. Zirngiebl (Eds.), Atlas of social innovation: New practices for a better future (pp. 26-29). Dortmund: Sozialforschungsstelle, TU Dortmund University.

Neslin, S. A., Grewal, D., Leghorn, R., Shankar, V., Teerling, M. L., Thomas, J. S., \& Verhoef, P. C. (2006). Challenges and opportunities in multichannel customer management. Journal of Service Research, 9(2), 95-112.

Nowotny, H., Scott, P., \& Gibbons, M. (2001). Re-thinking science: Knowledge and the public in an age of uncertainty. Cambridge: Polity Press.

Nyseth, T., \& Viken, A. (Eds.). (2009). Place reinvention: Northern perspectives. Farnham: Ashgate.

Olsson, A. K., \& Bernhard, I. (2018). Residents' attitudes 
towards city transformation: Place development in a smaller Swedish city. Paper presented at the 21th Uddevalla Symposium, Luleå, Sweden.

Öner, Ö. (2017). Retail city: The relationship between place attractiveness and accessibility to shops. Spatial Economic Analysis, 12(1), 72-91.

Oppewal, H., Alexander, A., \& Sullivan, P. (2006). Consumer perceptions of corporate social responsibility in town shopping centres and their influence on shopping evaluations. Journal of Retailing and Consumer Services, 13(4), 261-274.

Pazder, D. (2011). The conception of cultural space revitalization as a way to increase downtown attractiveness. A case study of chosen medium-sized towns in the wielkopolska region. Quaestiones Geographicae, 30(4), 63-67.

Pine, J., \& Gilmore, J. H. (1999). The experience economy. Boston, MA: Harvard Business Review Press.

Piteå kommun. (2018a). Destination Piteå. Retrieved from www.destinationpitea.se

Piteå kommun. (2018b). Piteå Municipality. Retrieved from www.pitea.se

Pressman, N. (2004). Shaping cities for winter: Climatic comfort and sustainable design. Prince George: Winter Cities Association.

Rabbiosi, C. (2015). Renewing a historical legacy: Tourism, leisure shopping and urban branding in Paris. Cities, 42, 195-203.

Regeringen. (2018). The Swedish Government. Retrieved from www.regeringen.se

Region Norrbotten. (2018). Region Norrbotten. Retrieved from www.norrbotten.se

Resurs. (2016). TEM 2016 PITEÅ. Ekonomiska och sysselsättningsmässiga effekter av turismen i Piteå kommun 2016 [Economic and employment effects of tourism in Piteå 2016]. Stockholm: Resurs.

Rönkkö, E. (2014). Actions on urban health enhancement in the Arctic: Salutogenic planning concept. In Proceedings of the 6th annual architectural research symposium. Oulu: Nordic Association of Architectural Research Conference (NAAR).

Russo, A. P., \& Van Der Borg, J. (2002). Planning considerations for cultural tourism: A case study of four European cities. Tourism Management, 23(6), 631-637.

Sandahl, J., \& Lindh, C. (1995). Impact of improving the attractiveness of town centres. Transport Policy, 2(1), 51-56.

Saraiva, M., \& Pinho, P. (2017). Spatial modelling of commercial spaces in medium-sized cities. GeoJournal, 82(3), 433-454.

Schmitt, B. H. (2003). Customer experience management. Hoboken, NJ: John Wiley \& Sons.

Silverman, D. (Ed.). (1997). Qualitative research: Theory, method and practice. London: SAGE.
Statistics Sweden. (2016). Piteå municipal facts. Stockholm: Statistics Sweden.

Sundbo, J., \& Sørensen, F. (Eds.). (2013). Handbook on the experience economy. Cheltenham: Edward Elgar.

Syssner, J. (2010). Place branding from a multi-level perspective. Place Branding and Public Diplomacy, 6(1), 36-48.

Teale, M. (2013). The challenges of attracting investment back to the High Street. Journal of Urban Regeneration and Renewal, 6(2), 154-163.

Teller, C., Alexander, A., \& Floh, A. (2016). The impact of competition and cooperation on the performance of a retail agglomeration and its stores. Industrial Marketing Management, 52, 6-17.

Teller, C., \& Elms, J. (2010). Managing the attractiveness of evolved and created retail agglomerations formats. Marketing Intelligence and Planning, 28(1), 25-45.

Teller, C., \& Elms, J. (2012). Urban place marketing and retail agglomeration customers. Journal of Marketing Management, 28(5/6), 546-567.

Tyréns. (2014). Handelsstudie Piteå [Retail study Piteå]. Stockholm: Tyréns.

Valls, J. F., Sureda, J., \& Valls-Tuñon, G. (2014). Attractiveness analysis of European tourist cities. Journal of Travel and Tourism Marketing, 31(2), 178-194.

Vural-Arslan, T., Dostolu, N., Köprülü-Babanci, Ö., \& Aknctürk, N. (2011). Sustainable revitalisation as a tool for regenerating the attractiveness of an innercity historic commercial district: Han District as a case. Urban Design International, 16(3), 188-201.

Wahlberg, O. (2016). Small town centre attractiveness: Evidence from Sweden. International Journal of Retail and Distribution Management, 44(4), 465-488.

Warnaby, G., \& Medway, D. (2004). The role of place marketing as a competitive response by town centres to out-of-town retail developments. The International Review of Retail, Distribution and Consumer Research, 14(4), 457-477.

Weltevreden, J. W. J., \& Van Rietbergen, T. (2007). Eshopping versus city centre shopping: The role of perceived city centre attractiveness. Tijdschrift voor Economische en Sociale Geografie, 98(1), 68-85.

Western Dock. (2018). Western dock. Retrieved from www.vastrakajen.se

Yin, R. K. (2009). Case study research: Design and methods. London: SAGE.

Zenker, S. (2011). How to catch a city? The concept and measurement of place brands. Journal of Place Management and Development, 4(1), 40-52.

Zenker, S., Braun, E., \& Petersen, S. (2017). Branding the destination versus the place: The effects of brand complexity and identification for residents and visitors. Tourism Management, 58, 15-27. 


\section{About the Authors}

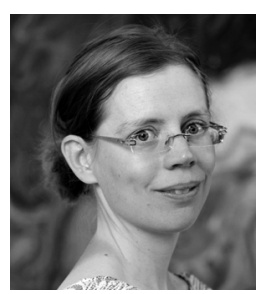

Malin Lindberg is a Professor of Industrial Design at Luleå University of Technology, Sweden. Her research concerns inclusive innovation and organization, with a specific focus on social innovation, place innovation, and gender-equal innovation. Her work has appeared in journals such as International Journal of Innovation Management, International Journal of Innovation and Regional Development, and the International Journal of Social Entrepreneurship and Innovation.

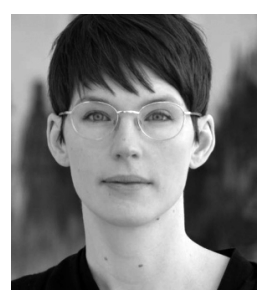

Kristina Johansson, PhD, is an Assistant Professor of Human Work Science at Luleå University of Technology, Sweden. Her research concerns gender, work, and organizations in retail and industry settings. Her work has appeared in journals such as Men and Masculinities and Gender, Work and Organization.

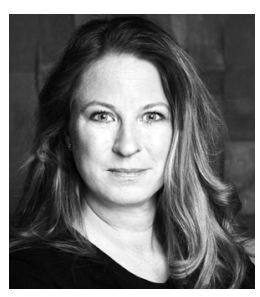

Helena Karlberg is CEO at Piteå Science Park, which promotes cultural and creative industries, as well as Cleantech industries in northern Sweden. She is also a board member of Swedish Incubators and Science Parks (SISP), and part of Sweden's Regional Policy Forum Steering Committee. She has a background as a journalist and business promoter, and has participated in several R\&D projects on place innovation and social innovation.

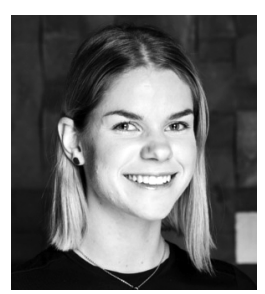

Johanna Balogh is Innovation Manager at Piteå Science Park, which promotes cultural and creative industries, as well as Cleantech industries in northern Sweden. With an educational background in product design, she specializes in place innovation, open innovation, and graphic recording. She partly works as a supervisor for students in innovation courses. 